\title{
Students' Readiness on Online Distance Learning (ODL)
}

\author{
Zulaikha Khairuddin $^{1}$, Nik Nur Athirah Nik Mohd Arif ${ }^{2}$, Zurina Khairuddin ${ }^{3, *}$ \\ ${ }^{1}$ Akademi Pengajian Bahasa, Universiti Teknologi MARA, 40000 Shah Alam, Malaysia \\ ${ }^{2}$ Pusat Bahasa Dan Pengajian Umum, Universiti Pendidikan Sultan Idris, 35900 Tanjong Malim, Perak, Malaysia \\ ${ }^{3}$ Faculty of Languages and Communication, Universiti Sultan Zainal Abidin, 21300 Kuala Terengganu, Malaysia
}

Received September 14, 2020; Revised October 25, 2020; Accepted November 25, 2020

\section{Cite This Paper in the following Citation Styles}

(a): [1] Zulaikha Khairuddin, Nik Nur Athirah Nik Mohd Arif, Zurina Khairuddin, "Students' Readiness on Online Distance Learning (ODL)," Universal Journal of Educational Research, Vol. 8, No. 12, pp. 7141 - 7150, 2020. DOI: 10.13189/ujer.2020.081281.

(b): Zulaikha Khairuddin, Nik Nur Athirah Nik Mohd Arif, Zurina Khairuddin (2020). Students' Readiness on Online Distance Learning (ODL). Universal Journal of Educational Research, 8(12), 7141 - 7150. DOI: 10.13189/ujer.2020.081281.

Copyright@2020 by authors, all rights reserved. Authors agree that this article remains permanently open access under the terms of the Creative Commons Attribution License 4.0 International License

\begin{abstract}
The current demand of education has changed the teaching and learning processes from traditional face-to-face learning to online distance learning (ODL). This study aims to explore students' readiness in experiencing ODL. This study utilised quantitative approach to obtain the data. The instrument used was questionnaire with seven sections. The questionnaire was distributed to the Diploma and Bachelor's Degree students from public and private universities. The data were analysed using SPSS v 25 software and presented in the tables in the form of means, t-test and one-way ANOVA. Based on the results, there is a significant difference between students of different levels of education in terms of their readiness to undergo ODL. The six aspects of ODL readiness significantly determine how ready the students were in terms of availability of technology, use of technology, self-confidence, acceptance, self-directed learning, and training. It can be concluded that most of students seemed to be unsure whether they were ready to experience ODL in the aspects of the availability of technology and their acceptance to learn through ODL. Other than that, the students are almost ready in adapting themselves to go through ODL. The significant stakeholders such as, universities, faculties and educators need to have better understanding of students' readiness to undergo ODL and be prepared to experience more of ODL.
\end{abstract}

Keywords Online Distance Learning (ODL), Students' Readiness, Challenges, COVID-19

\section{Introduction}

The new normal of education has urged the higher educational institution to undergo online distance learning (ODL). The implementation of online learning used to be considered as a solution to fulfil the increasing demand of students enrolling in higher education especially those who are unable to be full-time students [1]. However, the current demand of education has transformed the traditional face-to-face learning to ODL in ensuring the continuity of teaching and learning process. [1] acknowledged the working adults as the students who are involved in online learning at the beginning, and recently online learning has involved all students, regardless of their status as full-time university students or distance learners. Educators across all disciplines from all over the world are extensively experimenting the online learning system as a viable mode of education [2]. Online learning refers to a mode of learning which both educators and students involve in distance learning requiring the integration of Internet and digital technology [3,4]. The rapid development of digital communication contributes to technology-mediated participation and synchronous online learning [5]. [1] describe online learning to be conducted with the application of electronic devices along with or without internet connection. This mode of learning promotes both synchronous and asynchronous learning environment. The delivery method of teaching can be done either as offline e-learning with the usage of digital devices or as online e-learning which focuses on both technology tools and internet connection [1]. 
According to [6], students' learning outcomes are the most important aspect for educators regardless which learning mode is used. ODL provides a learning environment without time and place restrictions following their speed of learning allowing students to manage their own learning schedule $[7,8]$. Distance education promotes self-regulated learning which can develop learners who are independent and self-regulated [9]. In ODL, students are in charge of their own learning process. The readiness of students for online learning will give positive impacts to students' academic performance and foster communication in learning environment [10]. Therefore, this study aims to determine students' readiness to undergo ODL. This could help instructors to construct an effective ODL that supports the students' need and acceptance of learning, and students' performance.

\section{Literature Review}

\subsection{Readiness of Online Distance Learning}

Students' readiness should be emphasized in ODL to promote significant learning experiences and outcomes. [10] suggest that students should possess online learning readiness to gain benefit from this online learning environment. [11] define online learning readiness as "the degree to which learners are ready to taking courses in online learning environment.”

Factors affecting online learning readiness among students include internet and technology-related self-efficacy, self-directed learning, learner control, learning motivation and online interaction self-efficacy [12]. Another two variables contributed to online learning readiness are the accessible learning resources and self-direction [13]. [12] discover that students' perceptions towards online learning are seen to be related with their academic performance. They further explain that positive perceptions on features related to online learning, for example interaction with peers and instructors, internet connectivity and technology availability, will contribute to students' readiness in adapting to online learning environment. [2] discovered that students in higher education institution were ready for e-learning and had the necessary technological skills. Thus, they believe that students' readiness can be improved with a proper planning in terms of the usage and availability of the technology, computer and internet efficacy, self-directed learning and students' behaviours [2].

According to [9], students' success as distance learners is linked with several characteristics including gender, age, educational level, locus of control, style of learning, motivational beliefs and self-regulated learning components. [14] stated that some students might face difficulty in adapting to the online learning as they should be fully responsible on their own learning and at the same time, they feel reluctant to forgo the traditional face-to-face instruction. Students' personality traits such as self-confidence level, self-knowledge, self-control and self-expression would influence their online learning readiness [10]. Moreover, it is believed that students' readiness might have a relationship with their emotional traits [10]. Students are expected to be able to control their own emotions and to understand others' emotions during online learning. Therefore, it is suggested that students should be included in making decision about learning process to ensure the success of the online learning implementation [7].

\subsection{Challenges of Online Distance Learning}

ODL has become a very familiar term nowadays since the pandemic of COVID-19 happens. ODL is defined as a learning process that happens not in classrooms and students do not have to be present physically as learning process is facilitated with the use of technology [15]. In other words, both educators and students can be anywhere they want to achieve the objective of the lesson as long as they have internet connection and they are equipped with the tools needed. However, there are challenges that need to be faced by the educators and students that experienced ODL. Accommodating the differences in students' learning styles and preferences is one of the challenges faced by the instructors and it should be acknowledged and considered when designing content which is delivered via technology [16]. Interaction between instructors-students, students and students, and students and course content facilitate learning in distance education environment [17].

[18] state that students face challenges during online learning due to lack of internet access, lengthy response time, and uninteresting learning content and materials. [19] stated among the challenges faced in online learning implementation were internet accessibility, technology devices and software. This view is supported by [2] as improvements are needed in the aspects of technology usage and availability, and computer and internet efficacy. In their study, [9] pointed out that instructors were facing problems with students who were unable to adapt to online learning. They further explained several factors contributed to failure of online learning which are lack of time management, lack of motivation and insufficient effort. Online learning anticipates more responsibility and self-discipline from the learners [20]. Other than that, collaborative learning is one of the challenges in ODL due to lack of face-to-face interaction [2].

According to [21], there are a few challenges faced by students which could be categorised as three aspects: management challenges, learning challenges and technical challenges. Based on results found by [21] in terms of management challenges, students could not balance and manage their time with work, education, family and social life. Other than that, the learning challenges that they face, 
they lack the interest and commitment towards their education lead to low self-confidence. Lastly, the technical challenges that students face are in terms of internet connection, computing skills and not sure of reliable sources [21]. Other challenges faced by students are there are too much to learn, limited sources from the educators, unfriendly system or tools used for learning process, not receiving comments from educators and time constraints [22]. These challenges faced by students may lead them to stressful and inconducive environment for learning. Hence, this study aims to investigate the level of students' readiness in ODL at tertiary level.

\section{Methodology}

This study utilised quantitative approach to obtain the data. The instrument used was questionnaire. The questionnaire was adopted and adapted from [23,24,25,26]. The use of questionnaire is to get an overview and responses from the respondents in a large scale. The questionnaire is important to ensure that the data were collected in a standardised way so that it would help in analysing the data consistently and coherently [27]. Table 1 indicates the result of the reliability test for the instrument and the items with Cronbach's Alpha score of 0.980. This means the instrument was reliable.

\begin{tabular}{cc}
\hline \multicolumn{2}{c}{ Reliability Test } \\
\hline Cronbach's Alpha & $\mathrm{N}$ of items \\
.098 & 95 \\
\hline
\end{tabular}

In this questionnaire, there were seven (7) sections. The sections were:

Section A: Demographic Details

Section B: Availability of Technology

Section C: Use of Technology

Section D: Self Confidence

Section E: Acceptance

Section F: Self-Directed Learning

Section G: Training

The questionnaire was distributed randomly via google form and managed to obtain 424 responses where 118 were male students and 306 were female students. The respondents of this research were tertiary students from Diploma $(\mathrm{N}=359)$ and Bachelor's Degree $(\mathrm{N}=65)$ levels of study. Among the 424 respondents, there were 195 first-year students, 167 second-year students, 29 third-year students and 33 final year students. The respondents were from both public and private universities. The data were then analysed using SPSS v 25 software and presented in the tables in the form of means, t-test and one-way
ANOVA.

\section{Results and Discussion}

\subsection{Students' Readiness on Online Distance Learning (ODL)}

Table 1 shows the means for students' readiness to undergo online learning distance (ODL) based on six aspects: availability of technology, use of technology, self-confidence, acceptance, self-directed learning and training.

Table 1. Descriptive Statistics of Online distance learning readiness aspects

\begin{tabular}{|c|c|c|}
\hline & Mean & Std. Deviation \\
\hline Availability of Technology & 3.3479 & .74526 \\
\hline Use of Technology & 3.5612 & .57312 \\
\hline Self Confidence & 3.5510 & .65225 \\
\hline Acceptance & 3.1856 & .72769 \\
\hline Self-Directed L earning & 3.4800 & .68752 \\
\hline Training & 3.5241 & .77220 \\
\hline
\end{tabular}

Table 1 reveals the highest mean is 3.5612 for 'Use of technology'. This suggests that Malaysian students in this study somewhat agree that they were ready to use technology for ODL. They were ready to use the various software and online systems that are required of them. Their readiness in using multiple technology devices may affect their ODL experience positively as mentioned by [10]. This also reflects what was suggested by [12] and [2]: having positive perception towards using the technology would affect students' readiness in ODL.

Table 1 also reveals that the lowest mean is 3.1856 for 'Acceptance' which suggests these students were neutral in their readiness level to experience ODL. In other words, the students were unsure whether they were ready to undergo ODL. This could probably be caused by the possibility that they might have problems in adapting themselves to learn online $[14,10]$.

\subsection{T-Test (Level of Study)}

The study also aims to identify if there is a significant difference in students' readiness in undergoing ODL based on their levels of study. Therefore, this part discusses the difference between diploma and degree students by discussing means and the result of the independent sample $t$ - test of each aspect in ODL readiness. 
Table 2. Group Statistics

\begin{tabular}{|c|c|c|c|}
\hline & $\begin{array}{c}\text { LEVEL OF } \\
\text { STUDY }\end{array}$ & Mean & $\begin{array}{c}\text { Std. } \\
\text { Deviation }\end{array}$ \\
\hline $\begin{array}{c}\text { Availability of } \\
\text { Technology }\end{array}$ & DIPLOMA & 3.3510 & .73877 \\
\hline Use of Technology & DIPLOMA & 3.5877 & .55531 \\
\hline & DEGREE & 3.4143 & .64819 \\
\hline Self Confidence & DIPLOMA & 3.5468 & .63745 \\
\hline & DEGREE & 3.5744 & .73366 \\
\hline Acceptance & DIPLOMA & 3.1781 & .73155 \\
\hline Self-Directed & DEGREE & 3.2267 & .71016 \\
\hline Learning & DIPLOMA & 3.4926 & .67970 \\
\hline Training & DEGREE & 3.4099 & .73076 \\
\hline & DIPLOMA & 3.5604 & .74706 \\
\hline
\end{tabular}

Table 2 shows the difference based on the students' levels of study in terms of whether they were ready to undergo ODL. The means of each aspect reveal that there is a slight difference between students from degree and diploma levels in terms of the six aspects.

\subsection{Independent T-Test (Level of Study)}

Table 3 shows the independent sample $t$ - test result for students' readiness in ODL based on their levels of study: diploma and degree. (Refer to Appendix A)

This table reveals that the significant value for the Levene's tests for all aspects is more than .05 . This value means the equal variances for these aspects are assumed. Looking in the Equal Variances assumed row, the probability in the significant two - tailed column (p-value) is less than .05 for the aspects: use of technology and training. This means that there is a significant difference between degree and diploma students in terms of whether they are ready in terms of using the technology and training needs for ODL. This is similar to what was found by [9]: students who are distance learners may be influenced by their educational level in determining their success in ODL. However, for other aspects of ODL such as availability of technology, self-confidence, Self-Directed Learning and Acceptance, the p-value is more than .05 which means there is no significant difference between degree and diploma students. These aspects different from [9] could highly likely be caused by their similarities among the students who experience similar education system and their access to technology.

\subsection{ANOVA (Year of Study)}

Table 4 reveals the result of One - Way ANOVA test for all six aspects of ODL readiness. (Refer to Appendix B)

From Table 4, it can be seen that the p-values for the aspects use of technology and self-confidence are .046 and .023 respectively which are less than .05 . These values mean there is a significant difference among the four groups: first-year, second-year, third-year and final year, for these two aspects. This reflects the findings by [9] who found that students of different age and levels of study have different levels of readiness to undergo ODL particularly in using technology and their confidence level. This is likely to happen because older students are more likely to have higher confidence level as they have experienced more ODL compared to the younger ones. The situation is probably similar to those of different education levels because students who are in the upper level of education are commonly older. However, the table shows that there is no significant difference in terms of availability of technology, acceptance, self-directed learning and training based on their years of study.

Finally, the result of Post Hoc Tests Multiple Comparison is discussed.

\subsection{Post Hoc (Year of Study)}

Table 5 reveals the result of Post Hoc Tests Multiple Comparison for students' readiness to undergo ODL. (Refer Appendix C)

The table shows that the p-value for the aspect availability of technology between first year and final year students is .036 which is less than .05 , which means there is a significant difference between the two groups. This suggests that the first year and final year students have different levels of readiness when it comes to the technology available to them. The table also reveals that the p-value for self-directed learning is less than .05 (p-.013) suggesting that there is a significant difference between second and final year students. This means that the difference in terms of levels of readiness when it comes to self-directed learning is significant. For the aspects use of technology, self-confidence and acceptance, the table shows that there is a significant difference between first-year and final-year, second-year and final-year and third-year and final-year as the p-values between these groups are more than .05 . This suggests that the different years of study significantly determine how ready the students are in terms of their use of technology, how confident they are and their acceptance towards ODL.

The result from Table 5 demonstrates how Malaysian students of different levels of are different in terms of their readiness to experience ODL. It is apparent from this table that there is a significant difference between first-year and final year students when it comes to most aspects of ODL, namely availability of technology, use of technology, self-confidence and acceptance. In fact, for the aspects such as use of technology, self-confidence and acceptance show that students who are in their first year, second year and third year are significantly different to those who are in their final year. As previously mentioned, the results from 
Table 5 are similar to what was found by [9]: two factors affecting the students' readiness to undergo ODL are age and level of study.

\section{Conclusion}

In conclusion, acknowledging students' readiness to learn through ODL is indeed important. Hence, this study aims to explore students' readiness in experiencing ODL. Based on the results, it can be concluded that most of students seems to be unsure of their readiness in terms of the availability of technology and their acceptance to learn through ODL.

Other than that, the students are also likely to agree that they are ready in the use of technology, in their self-confidence level to learn via ODL, to practise self-directed learning and to have training to prepare them better for ODL. Thus, it can be said that students are almost ready to be more independent towards their learning process facilitated with the technology that is available.

\subsection{Pedagogical Implications}

Based on the results, it indicates that the stakeholders such as, universities, faculties and educators need to be prepared to experience more of ODL. This is due to the level of students' readiness where most of them agree that they are almost ready to undergo ODL in the future. This situation is also supported by the evolution of the technology that has evolved rapidly every year.

Moreover, students nowadays are among digital natives where they are more familiar with the use of technology such as using gadgets and surfing the internet in their daily life [28]. Hence, educators need to be more up-to-date in the advancement of technology used in education and they also have to be more advanced than the students. This is because the educators have to be more prepared in designing the lesson plans in the future. Thus, more training should be held to equip both educators and students with the knowledge needed in conducting ODL.

Based on the results obtained in the present study, it is suggested for other researchers to conduct a study using qualitative research method to have better understanding of students' readiness to undergo ODL. This is where researchers can have more in-depth data to be analysed to cater to students' needs and be current in the technology in education. Thus, future studies can support the data from current study qualitatively. 


\section{Appendix A}

Table 3. Independent Samples Test (students' level of study)

\begin{tabular}{|c|c|c|c|c|c|c|c|c|c|c|}
\hline & & $\begin{array}{l}\text { Levene's } \\
\text { Test for } \\
\text { Equality } \\
\text { of } \\
\text { Variances } \\
\end{array}$ & & $\begin{array}{l}\text { t-test for } \\
\text { Equality } \\
\text { of } \\
\text { Means }\end{array}$ & & & & & & \\
\hline & & $\mathrm{F}$ & Sig. & $\mathrm{t}$ & df & $\begin{array}{c}\text { Sig. } \\
\text { (2-tailed) }\end{array}$ & $\begin{array}{c}\text { Mean } \\
\text { Difference }\end{array}$ & $\begin{array}{l}\text { Std. Error } \\
\text { Difference }\end{array}$ & $\begin{array}{c}95 \% \\
\text { Confidence } \\
\text { Interval of } \\
\text { the } \\
\text { Difference }\end{array}$ & \\
\hline & & & & & & & & & Lower & Upper \\
\hline \multirow[t]{2}{*}{$\begin{array}{l}\text { Availability } \\
\text { of } \\
\text { Technology }\end{array}$} & $\begin{array}{c}\text { Equal } \\
\text { variances } \\
\text { assumed } \\
\end{array}$ & .176 & .675 & .201 & 422 & .841 & .02021 & .10057 & -.17748 & .21789 \\
\hline & $\begin{array}{c}\text { Equal } \\
\text { variances } \\
\text { not } \\
\text { assumed } \\
\end{array}$ & & & .192 & 85.726 & .848 & .02021 & .10499 & -.18851 & .22892 \\
\hline \multirow[t]{2}{*}{$\begin{array}{c}\text { Use of } \\
\text { Technology }\end{array}$} & $\begin{array}{c}\text { Equal } \\
\text { variances } \\
\text { assumed } \\
\end{array}$ & 1.722 & .190 & 2.256 & 422 & .025 & .17346 & .07688 & .02234 & .32458 \\
\hline & $\begin{array}{c}\text { Equal } \\
\text { variances } \\
\text { not } \\
\text { assumed } \\
\end{array}$ & & & 2.027 & 81.881 & .046 & .17346 & .08557 & .00322 & .34369 \\
\hline \multirow[t]{2}{*}{$\begin{array}{c}\text { Self } \\
\text { Confidence }\end{array}$} & $\begin{array}{c}\text { Equal } \\
\text { variances } \\
\text { assumed }\end{array}$ & 2.726 & .100 & -.313 & 422 & .754 & -.02755 & .08802 & -.20056 & .14545 \\
\hline & $\begin{array}{c}\text { Equal } \\
\text { variances } \\
\text { not } \\
\text { assumed } \\
\end{array}$ & & & -.284 & 82.416 & .777 & -.02755 & .09702 & -.22054 & .16543 \\
\hline \multirow[t]{2}{*}{ Acceptance } & $\begin{array}{c}\text { Equal } \\
\text { variances } \\
\text { assumed }\end{array}$ & .259 & .611 & -.495 & 422 & .621 & -.04859 & .09818 & -.24157 & .14438 \\
\hline & $\begin{array}{c}\text { Equal } \\
\text { variances } \\
\text { not } \\
\text { assumed } \\
\end{array}$ & & & -.505 & 90.359 & .615 & -.04859 & .09617 & -.23965 & .14246 \\
\hline \multirow[t]{2}{*}{$\begin{array}{l}\text { Self-Directed } \\
\text { Learning }\end{array}$} & $\begin{array}{c}\text { Equal } \\
\text { variances } \\
\text { assumed }\end{array}$ & .634 & .426 & .893 & 422 & .373 & .08275 & .09270 & -.09946 & .26496 \\
\hline & $\begin{array}{c}\text { Equal } \\
\text { variances } \\
\text { not } \\
\text { assumed } \\
\end{array}$ & & & .849 & 85.247 & .398 & .08275 & .09748 & -.11106 & .27656 \\
\hline \multirow[t]{2}{*}{ Training } & $\begin{array}{c}\text { Equal } \\
\text { variances } \\
\text { assumed } \\
\end{array}$ & 4.374 & .037 & 2.292 & 422 & .022 & .23737 & .10357 & .03379 & .44095 \\
\hline & $\begin{array}{c}\text { Equal } \\
\text { variances } \\
\text { not } \\
\text { assumed }\end{array}$ & & & 2.049 & 81.628 & .044 & .23737 & .11582 & .00695 & .46779 \\
\hline
\end{tabular}




\section{Appendix B}

Table 4. ANOVA

\begin{tabular}{|c|c|c|c|c|c|c|}
\hline & & Sum of Squares & df & Mean Square & $\mathrm{F}$ & Sig. \\
\hline \multirow[t]{3}{*}{ Availability of Technology } & Between Groups & 2.589 & 3 & .863 & 1.560 & .198 \\
\hline & Within Groups & 232.349 & 420 & .553 & & \\
\hline & Total & 234.938 & 423 & & & \\
\hline \multirow[t]{3}{*}{ Use of Technology } & Between Groups & 2.617 & 3 & .872 & 2.687 & .046 \\
\hline & Within Groups & 136.323 & 420 & .325 & & \\
\hline & Total & 138.940 & 423 & & & \\
\hline \multirow[t]{3}{*}{ Self Confidence } & Between Groups & 4.033 & 3 & 1.344 & 3.209 & .023 \\
\hline & Within Groups & 175.926 & 420 & .419 & & \\
\hline & Total & 179.959 & 423 & & & \\
\hline \multirow[t]{3}{*}{ Acceptance } & Between Groups & 3.747 & 3 & 1.249 & 2.382 & .069 \\
\hline & Within Groups & 220.246 & 420 & .524 & & \\
\hline & Total & 223.994 & 423 & & & \\
\hline \multirow[t]{3}{*}{ Self-Directed Learning } & Between Groups & 3.037 & 3 & 1.012 & 2.159 & .092 \\
\hline & Within Groups & 196.910 & 420 & .469 & & \\
\hline & Total & 199.947 & 423 & & & \\
\hline \multirow[t]{3}{*}{ Training } & Between Groups & .570 & 3 & .190 & .317 & .813 \\
\hline & Within Groups & 251.664 & 420 & .599 & & \\
\hline & Total & 252.235 & 423 & & & \\
\hline
\end{tabular}

\section{Appendix C}

Table 5. Multiple Comparisons

\begin{tabular}{|c|c|c|c|c|c|c|c|}
\hline LSD & & & & & & & \\
\hline \multirow[t]{2}{*}{ Dependent Variable } & $\begin{array}{l}\text { (I) YEAR OF } \\
\text { STUDY }\end{array}$ & $\begin{array}{l}\text { (J) YEAR OF } \\
\text { STUDY }\end{array}$ & $\begin{array}{c}\text { Mean } \\
\text { Difference (I-J) }\end{array}$ & Std. Error & Sig. & $\begin{array}{c}\text { 95\% Confidence } \\
\text { Interval } \\
\end{array}$ & \\
\hline & & & & & & Lower Bound & $\begin{array}{l}\text { Upper } \\
\text { Bound }\end{array}$ \\
\hline \multirow[t]{12}{*}{$\begin{array}{c}\text { Availability of } \\
\text { Technology }\end{array}$} & FIRST YEAR & $\begin{array}{l}\text { SECOND } \\
\text { YEAR }\end{array}$ & .02946 & .07842 & .707 & -.1247 & .1836 \\
\hline & & THIRD YEAR & .10813 & .14803 & .466 & -.1828 & .3991 \\
\hline & & FINAL YEAR & $.29378^{*}$ & .14000 & .036 & .0186 & .5690 \\
\hline & $\begin{array}{l}\text { SECOND } \\
\text { YEAR }\end{array}$ & FIRST YEAR & -.02946 & .07842 & .707 & -.1836 & .1247 \\
\hline & & THIRD YEAR & .07867 & .14963 & .599 & -.2154 & .3728 \\
\hline & & FINAL YEAR & .26432 & .14169 & .063 & -.0142 & .5428 \\
\hline & THIRD YEAR & FIRST YEAR & -.10813 & .14803 & .466 & -.3991 & .1828 \\
\hline & & $\begin{array}{l}\text { SECOND } \\
\text { YEAR }\end{array}$ & -.07867 & .14963 & .599 & -.3728 & .2154 \\
\hline & & FINAL YEAR & .18565 & .18932 & .327 & -.1865 & .5578 \\
\hline & FINAL YEAR & FIRST YEAR & $-.29378 *$ & .14000 & .036 & -.5690 & -.0186 \\
\hline & & $\begin{array}{l}\text { SECOND } \\
\text { YEAR }\end{array}$ & -.26432 & .14169 & .063 & -.5428 & .0142 \\
\hline & & THIRD YEAR & -.18565 & .18932 & .327 & -.5578 & .1865 \\
\hline \multirow[t]{2}{*}{ Use of Technology } & FIRST YEAR & $\begin{array}{c}\text { SECOND } \\
\text { YEAR }\end{array}$ & -.07116 & .06007 & .237 & -.1892 & .0469 \\
\hline & & THIRD YEAR & -.11834 & .11339 & 297 & -.3412 & 1045 \\
\hline
\end{tabular}


Table 5. Continued

\begin{tabular}{|c|c|c|c|c|c|c|c|}
\hline & & FINAL YEAR & $.21492 *$ & .10724 & .046 & .0041 & .4257 \\
\hline & $\begin{array}{l}\text { SECOND } \\
\text { YEAR }\end{array}$ & FIRST YEAR & .07116 & .06007 & .237 & -.0469 & .1892 \\
\hline & & THIRD YEAR & -.04718 & .11461 & .681 & -.2725 & .1781 \\
\hline & & FINAL YEAR & $.28608^{*}$ & .10853 & .009 & .0727 & .4994 \\
\hline & THIRD YEAR & FIRST YEAR & .11834 & .11339 & .297 & -.1045 & .3412 \\
\hline & & $\begin{array}{c}\text { SECOND } \\
\text { YEAR }\end{array}$ & .04718 & .11461 & .681 & -.1781 & .2725 \\
\hline & & FINAL YEAR & $.33326^{*}$ & .14501 & .022 & .0482 & .6183 \\
\hline & FINAL YEAR & FIRST YEAR & $-.21492 *$ & .10724 & .046 & -.4257 & -.0041 \\
\hline & & $\begin{array}{l}\text { SECOND } \\
\text { YEAR }\end{array}$ & $-.28608 *$ & .10853 & .009 & -.4994 & -.0727 \\
\hline & & THIRD YEAR & $-.33326^{*}$ & .14501 & .022 & -.6183 & -.0482 \\
\hline \multirow[t]{12}{*}{ Self Confidence } & FIRST YEAR & $\begin{array}{l}\text { SECOND } \\
\text { YEAR }\end{array}$ & -.03648 & .06824 & .593 & -.1706 & .0977 \\
\hline & & THIRD YEAR & -.16706 & .12881 & .195 & -.4203 & .0861 \\
\hline & & FINAL YEAR & $.30170^{*}$ & .12182 & .014 & .0622 & .5412 \\
\hline & $\begin{array}{l}\text { SECOND } \\
\text { YEAR }\end{array}$ & FIRST YEAR & .03648 & .06824 & .593 & -.0977 & .1706 \\
\hline & & THIRD YEAR & -.13059 & .13020 & .316 & -.3865 & .1253 \\
\hline & & FINAL YEAR & $.33818^{*}$ & .12329 & .006 & .0958 & .5805 \\
\hline & THIRD YEAR & FIRST YEAR & .16706 & .12881 & .195 & -.0861 & .4203 \\
\hline & & $\begin{array}{l}\text { SECOND } \\
\text { YEAR }\end{array}$ & .13059 & .13020 & .316 & -.1253 & .3865 \\
\hline & & FINAL YEAR & $.46876^{*}$ & .16473 & .005 & .1450 & .7926 \\
\hline & FINAL YEAR & FIRST YEAR & $-.30170 *$ & .12182 & .014 & -.5412 & -.0622 \\
\hline & & $\begin{array}{l}\text { SECOND } \\
\text { YEAR }\end{array}$ & $-.33818^{*}$ & .12329 & .006 & -.5805 & -.0958 \\
\hline & & THIRD YEAR & $-.46876^{*}$ & .16473 & .005 & -.7926 & -.1450 \\
\hline \multirow[t]{12}{*}{ Acceptance } & FIRST YEAR & $\begin{array}{l}\text { SECOND } \\
\text { YEAR }\end{array}$ & .01261 & .07635 & .869 & -.1375 & .1627 \\
\hline & & THIRD YEAR & -.11078 & .14412 & .443 & -.3941 & .1725 \\
\hline & & FINAL YEAR & $.32985^{*}$ & .13631 & .016 & .0619 & .5978 \\
\hline & $\begin{array}{l}\text { SECOND } \\
\text { YEAR }\end{array}$ & FIRST YEAR & -.01261 & .07635 & .869 & -.1627 & .1375 \\
\hline & & THIRD YEAR & -.12339 & .14568 & .397 & -.4097 & .1630 \\
\hline & & FINAL YEAR & $.31724^{*}$ & .13795 & .022 & .0461 & .5884 \\
\hline & THIRD YEAR & FIRST YEAR & .11078 & .14412 & .443 & -.1725 & .3941 \\
\hline & & $\begin{array}{l}\text { SECOND } \\
\text { YEAR }\end{array}$ & .12339 & .14568 & .397 & -.1630 & .4097 \\
\hline & & FINAL YEAR & $.44063^{*}$ & .18432 & .017 & .0783 & .8029 \\
\hline & FINAL YEAR & FIRST YEAR & $-.32985^{*}$ & .13631 & .016 & -.5978 & -.0619 \\
\hline & & $\begin{array}{l}\text { SECOND } \\
\text { YEAR }\end{array}$ & $-.31724^{*}$ & .13795 & .022 & -.5884 & -.0461 \\
\hline & & THIRD YEAR & $-.44063^{*}$ & .18432 & .017 & -.8029 & -.0783 \\
\hline \multirow[t]{6}{*}{$\begin{array}{l}\text { Self-Directed } \\
\text { Learning }\end{array}$} & FIRST YEAR & $\begin{array}{l}\text { SECOND } \\
\text { YEAR }\end{array}$ & -.08570 & .07219 & .236 & -.2276 & .0562 \\
\hline & & THIRD YEAR & .00461 & .13628 & .973 & -.2633 & .2725 \\
\hline & & FINAL YEAR & .24009 & .12888 & .063 & -.0132 & .4934 \\
\hline & $\begin{array}{l}\text { SECOND } \\
\text { YEAR }\end{array}$ & FIRST YEAR & .08570 & .07219 & .236 & -.0562 & .2276 \\
\hline & & THIRD YEAR & .09031 & .13775 & .512 & -.1805 & .3611 \\
\hline & & FINAL YEAR & $.32579 *$ & .13044 & .013 & .0694 & .5822 \\
\hline
\end{tabular}


Table 5 Continued

\begin{tabular}{|c|c|c|c|c|c|c|c|}
\hline & THIRD YEAR & FIRST YEAR & -.00461 & .13628 & .973 & -.2725 & .2633 \\
\hline & & $\begin{array}{c}\text { SECOND } \\
\text { YEAR }\end{array}$ & -.09031 & .13775 & .512 & -.3611 & .1805 \\
\hline & & FINAL YEAR & .23548 & . 17428 & .177 & -.1071 & .5781 \\
\hline & FINAL YEAR & FIRST YEAR & -.24009 & 12888 & .063 & -.4934 & .0132 \\
\hline & & $\begin{array}{c}\text { SECOND } \\
\text { YEAR }\end{array}$ & $-.32579 *$ & .13044 & .013 & -.5822 & -.0694 \\
\hline & & THIRD YEAR & -.23548 & .17428 & .177 & -.5781 & .1071 \\
\hline \multirow[t]{12}{*}{ Training } & FIRST YEAR & $\begin{array}{l}\text { SECOND } \\
\text { YEAR }\end{array}$ & -.04713 & .08161 & .564 & -.2076 & .1133 \\
\hline & & THIRD YEAR & -.00117 & .15406 & .994 & -.3040 & .3017 \\
\hline & & FINAL YEAR & -.12886 & .14571 & .377 & -.4153 & .1575 \\
\hline & $\begin{array}{c}\text { SECOND } \\
\text { YEAR }\end{array}$ & FIRST YEAR & .04713 & .08161 & .564 & -.1133 & .2076 \\
\hline & & THIRD YEAR & .04596 & .15572 & .768 & -.2601 & .3521 \\
\hline & & FINAL YEAR & -.08173 & .14746 & .580 & -.3716 & .2081 \\
\hline & THIRD YEAR & FIRST YEAR & .00117 & .15406 & .994 & -.3017 & .3040 \\
\hline & & $\begin{array}{c}\text { SECOND } \\
\text { YEAR }\end{array}$ & -.04596 & 15572 & .768 & -.3521 & .2601 \\
\hline & & FINAL YEAR & -.12769 & .19703 & .517 & -.5150 & .2596 \\
\hline & FINAL YEAR & FIRST YEAR & .12886 & .14571 & .377 & -.1575 & .4153 \\
\hline & & $\begin{array}{l}\text { SECOND } \\
\text { YEAR }\end{array}$ & .08173 & .14746 & .580 & -.2081 & .3716 \\
\hline & & THIRD YEAR & .12769 & 19703 & .517 & -.2596 & .5150 \\
\hline
\end{tabular}

\section{REFERENCES}

[1] A. A. Fahmeeda and L. C. Ming, "Review of e-Learning Practice at the Tertiary Education Level in Malaysia," Indian Journal of Pharmaceutical Education and Research, vol. 49, no. 4, pp. 248-257, Oct-Dec, 2015.

[2] D. Adams, B. Sumintono, A. Mohamed, A. and M. N. Nur Syafika, M. N, "E-Learning Readiness among Students of Diverse Backgrounds in a Leading Malaysian Higher Education Institution," Malaysian Journal of Learning and Instruction, vol. 15, no. 2, pp. 227-256, Dec, 2018.

[3] K. A. Al-Busaidi, “An empirical investigation linking learners' adoption of blended learning to their intention of full e-learning," Journal Behaviour \& Information Technology, vol. 32, no. 11, pp. 1168-1176, April, 2013. doi: https://doi.org/10.1080/0144929X.2013.774047

[4] A. Nor Aniza and L. N. Chua, “Technology and Higher Education: Using an E-Learning Tutorial as a Pedagogy for Innovation and Flexible Learning," Malaysian Journal of Distance Education, vol. 17, no. 1, pp. 21-31, 2015.

[5] I. Blau and A. Barak, "How Do Personality, Synchronous Media, and Discussion Topic Affect Participation?," Educational Technology \& Society, vol. 15, no. 2, pp. 12-24, 2012.
[6] W. Chyr, P. Shen, Y. Chiang, J. Lin and C. Tsai, "Exploring the Effects of Online Academic Help-seeking and Flipped Learning on Improving Students' Learning,” Educational Technology \& Society, vol. 20, no. 3, pp. 11-23, May, 2016.

[7] S. H. Chang and R. A. Smith, "Effectiveness of Personal Interaction in a Learner Centered Paradigm Distance Education Class Based on Student Satisfaction,” Journal of Research on Technology in Education, vol. 40, no. 4, pp. 407-426, 2008. doi:https://doi.org/10.1080/15391523.2008. 10782514

[8] B. Akkoyunlu and M. Y. Soylu, "A Study on Students' Views on Blended Learning Environment," Turkish Online Journal of Distance Education, vol. 7, no. 3, pp. 43-56, 2006.

[9] E. Yukselturk and S. Bulut. "Predictors for Student Success in an Online Course,” Educational Technology \& Society, vol. 10, no. 2, pp. 71-83, 2007.

[10] M. Engin, “Analysis of Students' Online Learning Readiness Based on Their Emotional Intelligence Level," Universal Journal of Educational Research, vol. 5, no. 12A, pp. 32-40, 2017.

[11] F. Alem, M. Plaisent, C. Zuccaro and P. Bernard, "Measuring e-Learning Readiness Concept: Scale Development and Validation Using Structural Equation Modeling," International Journal of e-Education, $e$-Business, e-Management and e-Learning, vol. 6, no. 4, pp. 193-207, 2016. 
[12] H. Wei and C. Chou, "Online learning performance and satisfaction: do perceptions and readiness matter?,” Journal Distance Education, vol. 41, no. 1, pp. 48-69, 2020. doi: https://doi.org/10.1080/01587919.2020.1724768

[13] P. J. Smith, K. L. Murphy and S. E. Mahoney, “Towards identifying factors underlying readiness for online learning: An exploratory study," Distance Education, vol. 24, no. 1, pp. 57-67, 2003. doi:https://doi.org/10.1080/015879103030 43

[14] N. Vaughan, "Perspectives on Blended Learning in Higher Education,” International Journal on E-Learning, vol. 24, no. 1. pp. 57-67, Jan, 2007.

[15] M. Sadeghi, “A Shift from Classroom to Distance Learning: Advantages and Limitations," International Journal of Research in English Education, vol. 4, no. 1, pp. 80-88, March, 2019. doi: 10.29252/ijree.4.1.80

[16] M. F. Sherina, M. F. Shahnaz and R. H. Raja Maznah, "Designing Instruction for Active and Reflective Learners in the Flipped Classroom," Malaysian Journal of Learning and Instruction, vol. 13, no. 2, pp. 147-173, 2016.

[17] Y. Zhao and S. Tan, "What makes the difference? A practical analysis of research onthe effectiveness of distance education," Teachers College Record, vol. 107, no. 8, pp. 1836-1884, 2005.

[18] M. A. Embi, “e-Learning in Malaysian institutions of higher learning: Status, trends and challenges," Paper presented at: International Lifelong Learning Conference (ICLLL 2011), Seri Pacific Hotel, Kuala Lumpur, 2011.

[19] O. S. Aboderin, "Challenges and Prospect of E-learning at National Open University of Nigeria,” Journal of Education and Learning, vol. 9, no. 3, pp. 207-216, 2015.

[20] V. Cantoni, M. Cellario and M. Porta, "Perspectives and challenges in e-learning: towards natural interaction paradigms," Journal of Visual Languages and Computing, vol. 15, no. 5, pp. 333-345, 2004.

[21] M. Kara, F. Erdoğdu, M. Kokoç and K. Cagiltay, "Challenges Faced by Adult Learners in Online Distance Education: A Literature Review,” Open Praxis, vol. 11, no. 1, pp. 5-22, January-March, 2019. doi:10.5944/openpraxis.11. 1.929

[22] O. T. Au, K. Li and T. M. Wong, "Student persistence in open and distance learning: success factors and challenges," Asian Association of Open Universities Journal, vol. 13, no. 2, pp. 191-202, 2018.

[23] Y. Ünal and I. Soydal., "Students Readiness for E-Learning: An Assessment on Hacettepe University Department of Information Management," Conference paper in Communications in Computer and Information Science, Jan, 2014. doi: 10.1007/978-3-662-44412-2_13

[24] M. Hung, C. Chou, C. Chen and Z. Own, "Learner readiness for online learning: Scale development and student perceptions,” Computer \& Education, vol. 55, no. 3, pp. 1080-1090, 2010.

[25] I. K. Forson and E. Vuopala, "Online Learning Readiness: Perspective of Students Enrolled in Distance Education in Ghana," The Online Journal of Distance Education and e-Learning, vol. 7, no. 4, pp. 277-294, Oct, 2019.

[26] S. Tuntirojanawong, “Students’ Readiness for E-Learning: A Case Study of Sukhothai Thammathirat Open University, Thailand,” Journal of Learning in Higher Education, vol. 9, no. 1, pp. 59-66, 2013.

[27] N. Mathers, N. Fox and A. Hunn, “The NIHR Research Design Service for the East Midlands, Survey and Questionnaires,” National Institute for Health Research, 2009.

[28] D. E. N. Rakhmawati and A. W. Kusuma, "Digital Native: A Study on the First-Year Student,” LiNGUA: Jurnal Ilmu Bahasa dan Sastra, vol. 10, no. 2, pp. 82-89, Dec, 2015. 